\title{
Retraction: Does changing from a first generation antipsychotic (perphenazin) to a second generation antipsychotic (risperidone) alter brain activation and motor activity? A case report
}

Jan Øystein Berle*, Else-Marie Løberg and Ole Bernt Fasmer

\section{Retraction}

The authors have retracted this article [1] as the fMRI data presented in the case report are incorrect. The activation data reported for session 1 are the activation data for session 2 and vice versa. As a result the discussion and conclusions of the case report are based on the wrong set of data and are no longer valid. The authors apologise for the error.

Received: 20 August 2013 Accepted: 20 August 2013

Published: 20 August 2013

\section{References}

1. Berle $\rfloor \varnothing$, Else-Marie L, Ole Bernt F: Does changing from a first generation antipsychotic (perphenazin) to a second generation antipsychotic (risperidone) alter brain activation and motor activity? A case report. BMC Research Notes 2013, 6:182.

Submit your next manuscript to BioMed Central and take full advantage of:

- Convenient online submission

- Thorough peer review

- No space constraints or color figure charges

- Immediate publication on acceptance

- Inclusion in PubMed, CAS, Scopus and Google Scholar

- Research which is freely available for redistribution 